\title{
KERAGAMAN JENIS DAN MODEL PRODUK HOME INDUSTRY KERAJINAN TANGAN SEBAGAI SUMBER BELAJAR DI SEKOLAH DASAR
}

\author{
Sumanto \\ Sukamti \\ Fakultas Ilmu Pendidikan, Universitas Negeri Malang \\ Jalan Semarang 5 Malang. \\ email: Sumantomunginan@gmail.com.
}

\begin{abstract}
The research aimed to describe: various types and models of handicrafts in Malang as learning source of cultural art and workshop of primary school. Qualitative descriptive approach. The subject of home industry of handicraft in Malang city. Data collection: observation, documentation and interview. Instrument of identity of handicraft place, owner's name, variety of craft product model. Result: (1) various bamboo root craft, wicker rattan, flower from corn "kelobot", fish scales, dried flowers, bouquet of flowers, banana pottery, handmade batik, fabric doll, flannel, knit, ceramic, furniture, frame, labunte, marble carving, cement sculpture, trash painting, painting, sanitair, stone mosaic, vandel, invitation card, screen printing, sandal carving, leather shoes, sand sea, and lanterns. (2) Handicraft models are mostly three-dimensional, and fewer two-dimensional shape.
\end{abstract}

Keywords: various, type, model, handicraft, learning resources, primary school.

\begin{abstract}
Abstrak: Penelitian bertujuan mendeskripsikan ragam jenis dan model kerajinan tangan di Kota Malang sebagai sumber belajar seni budaya dan prakarya SD. Pendekatan deskriptif kualitatif. Subyek home industry kerajinan tangan di Kota Malang. Pengumpulan data: observasi, dokumentasi dan wawancara. Instrumen identitas tempat kerajinan, nama pemilik, ragam model produk kerajinan. Hasil: (1) ragam kerajinan akar bambu, anyaman rotan, bunga klobot jagung, sisik ikan, bunga kering, merangkai bunga ucapan duka, gerabah/gerabah pisang, batik tulis, boneka kain, kain flanel, merajut, keramik, meubel, pigura, labunte, ukir batu marmer, patung semen, seni lukis tempat sampah, seni lukis, sanitair, mosaik batu, vandel, kartu undangan, cetak sablon, sandal ukir, sepatu kulit, pasir laut, dan lampion. (2) model kerajinan tangan sebagian besar berwujud tiga dimensi, dan sebagian kecil dua dimensi.
\end{abstract}

Kata Kunci: ragam, jenis, model, kerajinan tangan, sumber belajar, SD

Keberadaan bentuk aktivitas budaya yang dilakukan oleh sebagian masyarakat di Kota Malang adalah usaha pembuatan kerajinan tangan yangn menghasilkan benda-benda fungsional praktis, benda bernilai seni (benda hias), dan bernilai ekonomis. Produk kerajinan tersebut tentunya akan menjadi keragaman aset kerajinan daerah setempat. Kerajinan tangan (seni kria) adalah kegiatan yang berkaitan dengan pembuatan suatu barang atau produk yang dihasilkan dari kerja terampil tangan atau kegiatan yang berkaitan dengan barang yang dihasilkan melalui keterampilan tangan. Kerajinan/ kria adalah jenis karya seni rupa terapan (seni pakai) yang umumnya dihasilkan melalui kerja terampil para perajinnya (Sumanto, 2011). Keberadaan suatu kegiatan atau usaha (home industry) kerajinan 
tangan di kota Malang tersebut tentunya akan melahirkan ekspresi seni, gagasan kreatif produktif yang memiliki ciri atau karakteristik yang spesifik (khas) sesuai jenis dan model produk yang dihasilkannya.

Kerajinan tangan tersebar di lima wilayah kecamatan Kota Malang (Sukun, Klojen, Lowokwaru, Blimbing dan Kedungkandang). Kerajinan tangan tersebut adalah sebagai wujud perilaku budaya masyarakat, khususnya warga kota Malang yang memiliki keterampilan kreatif membuat aneka ragam produk yang bernilai seni dan ekonomis. Dalam hal ini dapat diapresiasi sebagai dampak adanya interaksi para Perajin, dunia usaha dalam membaca kebutuhan dan keinginan konsumen sehingga produk yang dihasilkan dapat memuaskan dan diminati oleh orang lain sebagai penggunanya. Wilayah Kota Malang yang ada di Kecamatan Blimbing, Kedungkandang, Sukun, Klojen dan Lowokwaru memiliki potensi sumber daya manusia yang dapat diberdayakan dalam pembuatan ragam produk kerajinan tangan. Pembuatan ragam produk kerajinan tangan dilakukan dengan memanfaatkan keberadaan bahan alam dan bahan buatan yang ada di lingkungan sekitar, atau dengan cara mendatangkan kebutuhan bahan (material) dari daerah/wilayah luar kota Malang. Melalui home industry kreatif kerajinan tangan diharapkan dapat mengangkat citra masyarakat lokal dan bahkan regional dilihat dari kualitas produk kerajinan dan banyaknya ragam model kerajinan yang dihasilkannya.

Dimiliknya kemampuan terampil kreatif para pengrajin di kota Malang mendorong adanya suatu keinginan untuk meningkatkan kesejahteraan diri, keluarga danan masyarakat setempat dengan memanfaatkan potensi berupa bahan alam yang ada di lingkungan sekitar, didukung pengetahuan dan keterampilan teknologi yang dipelajarinya. Beragam model benda-benda kerajinan dapat dibuat dari bahan alam atau bahan buatan yang dikerjakan dengan cara/teknik tertentu. Misalnya anyaman, keramik, ukir, batik, tenun, sulam dan sebagainya. Kerajinan tangan sebagai salah satu produk budaya dari Kota Malang dalam perkembangannya pada saat ini dapat memberikan makna budaya, dan nilai ekonomis bagi masyarakat sekitar sebagai pendukungnya.

Tinjauan empiris didasarkan pandangan Antropologi Budaya menunjukkan bahwa usaha kerajinan tangan yang dilakukan masyakat di Kota Malang memperlihatkan ciri berikut ini. (1) Fung- sional, artinya usaha kerajinan tangan yang dilakukan memiliki manfaat bagi diri Perajin dan orang lain (konsumen), serta mendapatkan dukungan dari komunitas masyarakat setempat. Fungsi tersebut diantaranya bisa dilihat dari fungsi ekonomi, fungsi edukatif, fungsi organisasi sosial, dan fungsi estetis (keindahan). (2) Sistimik, artinya adanya kaitan antara satu unsur dengan unsur yang lainnya. Dalam hal ini ada hubungan secara utuh antara unsur budaya (Perajin, Pengguna, Penikmat, aktivitas, ide/ gagasan), namun dibatasi dengan jelas perannya dari setiap unsur yang ada. (3) Terstruktur, yaitu pada ragam produk kerajinan tangan tersebut menampilkan adanya suatu pola atau struktur fisik sesuai visualisasi karya seni kerajinan tangan yang dihasilkannya (Sumanto, 2017:31).

Keberadaan pembuatan aneka ragam model atau bentuk benda kerajinan tangan tersebut tidak lepas dari dorongan keinginan dan kebutuhan dalam kehidupan manusia. Kerajinan tangan merupakan suatu produk hasil keterampilan manusia berupa hiasan, benda seni ataupun barang pakai untuk memenuhi kebutuhan manusia. Untuk membuat sebuah kerajinan tangan diperlukan suatu keterampilan. Pengrajin memperoleh keterampilan dengan cara belajar melalui orang lain maupun melalui pengalaman diri sendiri. Dengan memiliki keterampilan pengrajin akan dapat bertahan hidup dalam lingkungan yang selalu berubah.

Pekembangan sekarang ini disejumlah tempat yang ada di Kota Malang telah tumbuh dan berkembang usaha-usaha rumahan kerajinan baik yang dilakukan oleh perseorangan (keluarga) atau yang dilakukan oleh unit koperasi usaha kecil menengah. Dewasa ini di Indonesia kerajinan berkembang dalam kelompok masyarakat yang menempati strata social tertentu, yang memiliki kemampuan untuk memanfaatkan dan menikmati sumber daya lingkungan dengan maksimal seperti para elit pengusaha dan keluargannya (Rohidi, 2000). Setiap usaha kerajinan tangan yang dilakukan diduga memiliki permasalahan yang berkaitan dengan penyediaan material (bahan) yang digunakan, desain atau model karya/produk yang dihasilkan, kualitas teknis dalam pembuatanya, dan juga dalam pemasarannya serta keberlangsungan usaha yang dilakukannya. Dinyatakan Raharjo (2011) bahwa jenis seni kerajinan diklasifikasikan berdasarkan dari segi teknis dan paling populer meliputi: seni ukir, seni keramik, seni anyam, seni tenun, dan seni batik. 
Adanya keragaman model kerajinan tangan di Kota Malang, dan keberadaan Pengrajin berdasarkan observasi awal yang dilakukan peneliti dan mahasiswa PGSD FIP Universitas Negeri Malang tahun 2015 di Kecamatan Lowokwaru menunjukkan bahwa: (1) wilayah Lowokwaru kota Malang; khususnya di sekitar kelurahan Dinoyo cukup banyak pengrajin yang mampu membuat atau menghasilkan ragam model produk kerajinan tangan yang menarik dan penting untuk dikaji secara lebih faktual melalui kegiatan penelitian. (2) Sepengetahuan peneliti sampai saat ini belum secara terencana/terstruktur memanfaatkan keberadaan pengrajin dan keragaman model produk karya kerajinan dilingkungan setempat untuk dimanfaatkan sebagai sumber belajar SBdP di SD (Sumanto, 2017:33). Padahal dalam implementasi pendekatan saintifik dan keterpaduan pembelajaran di SD berdasarkan acuan kurikulum 2013 sangat relevan untuk mengembangkan materi muatan seni budaya dan prakarya dari potensi sumber belajar yang ada di lingkungan sekitar.

Oleh karena itu melalui penelitian pemetaan potensi kerajinan tangan di Kota Malang ini diharapkan dapat menjadi sumber informasi (sumber belajar) kontekstual bagi pendidikan khususnya pembelajaran SBdP di SD. Keberagaman model produk kerajinan tangan diyakini sebagai wujud budaya rupa yang bermanfaat untuk kegiatan pembelajaran bagi anak usia SD. Melalui aktivitas mengamati, menanya, dan digunakan untuk berekspresi kreatif mengenai ragam prakarya yang dilatihkan pada siswa SD. Vygotsky (2000) mengemukakan bahwa siswa mengkonstruksi pengetahuan atau menciptakan hubungan-hubungan bermakna antar unsur sebagai hasil pemikiran dan interaksinya dalam konteks sosial. Sedangkan Suprayekti (2004) mengemukakan bahwa pembelajaran berbasis budaya merupakan strategi penciptaan lingkungan belajar dan perancangan pengalaman belajar yang mengintegrasikan budaya sebagai bagian dari proses pembelajaran. Pemetaan dilakukan diantaranya bertujuan untuk mendeskripsikan keragaman dan model produk kerajinan tangan yang dihasilkan oleh pengrajin, keragaman teknik/cara pembuatan kerajinan tangan, dan keragaman jenis bahan (material) yang digunakan serta cara pengolahannya.

Penelitian yang difokuskan pada pemetaan home industry kerajinan tangan di Kota Malang ini didasarkan pada hasil penelitian sebelumnya yang telah peneliti lakukan di wilayah Kota dan Kabupaten Blitar (Sumanto, 2015) yang hasilnya sebagai berikut. (1) Ragam jenis kerajinan di Blitar yaitu Bandul Kunci, Tas, Kendang, Bros, Ketipung, Mahkota Sangkar Burung, Marakas, Bambu Kreatif, Gerabah, Kaca Lukis, Barongan, Ukir Kayu, Wayang, Batik, kertas dan lainnya. Jenis benda kerajinan hasil keterampilan kreatif para Pengrajin dalam mengolah atau memanfaatkan bahan alam dan bahan buatan secara umum modelnya sebagian berwujud dwimatra, sebagian besar berwujud tiga trimatra, dan sebagian kecil ada yang wujudnya cenderung dua-tiga dimensi. (2) Cukup banyak macam-macam teknik seni kerajinan tangan yang dilakukan secara manual berdasarkan keterampilan tangan pengrajin; atau teknik pembuatan kerajinan tangan melalui bantuan peralatan mesin. Diantara teknik seni kerajinan tersebut yaitu: Menganyam, Mengukir, Menjahit, Mengikat, Merangkai-Meronce, Merajut, Menempel, Menyulam, Membatik, Melipat, Membutsir, Pilin, Putar, Mencetak, Sablon, Melukis, Menoreh, Membubut. (3) Keragaman bahan (material) kerajinan dapat berupa bahan alam, bahan buatan pabrik, dan bahan limbah (sisa). Bahan alam diantaranya bambu, kayu, bunga segar/ kering, daun pandan, enceng gondok, serat, rotan, sabut kelapa, bathok kelapa, kulit binatang, biji-bijian kering, batu marmer dan sejenisnya. Bahan buatan pabrik diantaranya kertas, karton, plastik, pita, kain, benang, senar, mitasi, karet, tali, semen, aneka jenis cat, tinta, manik-manik, aluminium, seng, kawat, bahan logam lainnya. Bahan limbah diantaranya limbah kertas, limbah kayu, limbah logam, kain perca, serutan kayu, serbuk gergaji.

Kerajinan tangan sebagai sumber belajar yang kontektual dan aktual dapat dimanfaatkan oleh guru sebagai alat bantu mengajar dan bagi siswa sebagai sumber belajar sesuai dengan kompetensi hasil belajar yang akan dicapainya. Sumber belajar pada muatan materi SBdP dimaksudkan sebagai alat atau perantara antara siswa dengan pesan pembelajaran yang menjadi target capaian kompetensinya. Sanaky (2009:3) tentang pembelajaran menyatakan, dibutuhkan alat yang mampu menjadi penghantar dalam proses komunikasi tersebut. Dalam dunia pendidikan alat tersebut dikenal dengan sumber atau media pembelajaran. Media juga diartikan sebagai sarana pendidikan yang dapat digunakan sebagai perantara dalam proses pembelajaran untuk 
mempertinggi efektifitas dan efisiensi dalam mencapai tujuan pembelajaran (Sanaky, 2009:4).

Bentuk pemanfaatan kerajinan tangan sebagai sumber belajar diantaranya: (a) sebagai obyek yang dipelajari oleh siswa, (b) sebagai bahan pembelajaran berolah seni, bereksplorasi seni, (c) sebagai sumber ide dalam berolah seni, (d) sebagai obyek apresiasi, dan (e) sebagai model atau contoh tatanan seni (Sumanto. 2005). Kerajinan tangan sebagai sumber belajar dalam pemanfaatannya dapat dilakukan dengan cara mengapresiasi obyek dan aktivitas kerajinan tangan yang ada, atau dengan cara berkreasi kerajinan tangan sesuai tingkat kemampuan anak SD.

\section{METODE}

Sesuai tujuan penelitian, maka rancangan yang digunakan adalah deskriptif kualitatif. Menurut Bogdan dan Biklen (1992) desain kualitatif memiliki ciri: (1) natural setting, (2) bersifat deskriptif, (3) lebih mengutamakan proses dari pada hasil, (4) analisis data secara induktif, dan (5) makna merupakan perhatian utamanya. Pendekatan kualitatif menurut Sutopo (dalam Rokhmat, Triyanto \& Rondhi, 2004) sangat cocok dan memberi peluang dalam upaya memberikan pemahaman dan penjelasan secara kualitatif atas suatu fenomena secara mendalam dan holistik. Dalam mengkaji fenomena kerajinan tangan di Kota Malang didasarkan pada pendekatan kesenirupaan, pendekatan budaya pada wujud visualisasi produk kerajinan baik berdasarkan struktur fisik maupun struktur estetik, dan aktivitas kreatif pengrajin. Menurut Suharto (2007) pendekatan estetik melalui kritik seni. Pendekatan kritik seni sebelumnya hanya bersifat evaluatif. Melalui pendekatan ini suatu obyek seni dapat diamati dari aspek deskriptif, interpretative, dan evaluatif.

Sumber data diperoleh dari fakta aktivitas usaha kerajinan tangan yang dilakukan para pemilik usaha, pengrajin, produk kerajinan yang dihasilkan, teknik/cara pembuatan kerajinan, dan bahan serta peralatan kerajinan yang digunakan. Dalam hal ini peneliti bertindak sebagai instrumen yang berperan sebagai mengamat dan pengumpul data secara mendalam. Langkah kegiatannya: (a) survey pendahuluan yang meliputi kegiatan menemukan sumber pustaka dan hasil penelitian yang relevan, (b) pengumpulan data pemetaan kerajinan tangan di Kota Malang, (c) penelaahan dan reduksi data, (d) pe- nyajihan data paparan deskriptif untuk memberikan pemaknaan data.

Lokasi penelitian pemetaan kerajinan tangan ini berada di wilayah Kota Malang yang tersebar di 5 kecamatan yaitu Kecamatan Blimbing, Kedungkandang, Sukun, Klojen, dan Lowokwaru. Dari setiap wilayah kecamatan tersebut dipetakan tempat-tempat usaha kerajinan tangan yang pada saat penelitian ini dilakukan masih aktif memproduksi benda/karya kerajinan tangan. Lokasi home industry kerajinan tangan ada di setiap rumah para pengrajin atau pemilk usaha kerajinan baik yang dikelola secara perseorangan atau kelompok.

Subyek penelitian adalah usaha home industry kerajinan tangan yang ada di Kota Malang. Subyek penelitian ditentukan berdasarkan sampel wilayah yang mewakili sejumlah kecamatan di Kota Malang. Penentukan subyek penelitian disetiap wilayah kecamatan dan kelurahan dengan pertimbangan: (a) keberadaan home industry kerajinan tangan yang masih aktif memproduksi atau menghasilkan karya kerajinan tangan pada saat dilakukan pemetaan, (b) keterjangkauan tim peneliti untuk melakukan pemetaan home industry kerajinan tangan selama kurun waktu penelitian berlangsung, (c) wilayah kecamatan yang dijadikan subyek pemetaan merupakan daerah (kelurahan) penghasil karya kerajinan tangan di Kota Malang. Dari setiap wilayah kecamatan yang dipilih sebagai sampel dalam pengumpulan pemetaan home industry kerajinan tangan selanjutnya akan diambil sejumlah tempat usaha kerajinan tangan yang mewakili keragaman jenis kerajinan, keragaman model/produk kerajinan, teknik/cara pembuatan kerajinan tangan, dan memetakan bahan (material) serta cara pengolahannya.

Instrumen yang digunakan lembar pengamatan/ observasi identitas dan dokumentasi keberaadaan usaha kerajinan tangan mencakup aspek: asal/tempat usaha kerajinan, nama pemilik, keberadaan dan, produk kerajinan yang dibuat, teknik/cara pembuatan kerajinan, dan bahan (material) yang digunakan. Instrumen pedoman wawancara untuk menjaring data atau melengkapi data mengenai faktor pendukung dan kendala serta sumbangannya bagi pendidikan di SD. Analisis menggunakan pendekatan content analysis deskriptif kualitatif, yang menfokuskan perhatian pada penelaahan kritis terhadap suatu fenomena sebuah gejala berdasarkan fakta dan makna dari gejala tersebut. 


\section{HASIL}

\section{Keragaman Jenis Kerajinan Tangan sebagai Sumber Belajar SBdP SD}

Dari hasil pemetaan potensi keberadaan usaha perumahan (home industry) kerajinan tangan di Kota Malang menunjukkan ada keberagaman produk kerajinan yang memiliki nilai keindahan, dan nilai ekonomis yang dapat dimafaatkan sebagai sumber belajar di SD. Ragam jenis-jenis kerajinan di Malang tersebut dapat diberikan pembahasan sebagai berikut.

Pertama, berdasarkan letak atau lokasi usaha kerajinan tangan yang telah dipetakan yaitu berada di Kecamaatan Lowokwaru, Klojen, Sukun, Kedungkandang dan Blimbing. Kecamatan Lowokwaru cukup banyak usaha perumahan kerajinan tangan yang mampu menumbuhkan kehidupan ekonomi masyarakat, dan mampu meningkatkan produkproduk kerajinan baik berupa barang fungsional dan benda seni yang bernilai ekonomis. Bisa dinyatakan bahwa pertumbuhan usaha kerajinan tangan, atau sebagai sentral produksi kerajinan di Kota Malang sebagian besar berasal dari Kelurahan Dinoyo sebagai kampung keramik. Dari keberadaan potensi home industry kerajinan tangan yang telah dipetakan tersebut tentunya belum menggambarkan secara keseluruhan letak usaha kerajinan, jenis-jenis kerajinan tangan, keberadaan Pengrajin yang ada di wilayah Kota Malang. Dalam artian masih ada tempat usaha perumahan kerajinan tangan di wilayah Kota Malang yang belum dipetakan. Hal ini disebabkan karena adanya keterbatasan kemampuan peneliti untuk menjangkau, mendatangi, dan memetakan keseluruhan jenis-jenis kerajinan tangan yang berada disetiap kelurahan di Malang.

Secara umum hasil pemetaan jenis-jenis kerajinan tangan yang ada di Malang yaitu: Kerajinan Akar Bambu Galery 76 Kebon Agung No. 28 Kota Malang, Kerajinan Akar Bambu Krepek Dongklek, Kerajinan Anyaman Rotan, Kerajinan Klobot Jagung Garuda Jaya Florist Sawojajar Malang, Kerajinan Sisik Ikan dan Bunga Kering di Kota Malang, Kerajinan Merangkai Bunga Kering, Kerajinan Merangkai Bunga Ucapan Duka Cita, Kerajinan Gerabah Potleri Seni Kria, Kerajinan Gerabah Maron Jaya Art Shop Kota Malang, Kerajinan Tangan Gerabah Pisang (Graping), Kerajinan Gerabah Hias, Kerajinan Batik Tulis Celaket Kota Malang, Kerajinan Tangan Boneka Kain Bon- shop, Kerajinan Tangan Kain Flanel, Kerajinan Tangan Merajut di Sawojajar Kota Malang, Kerajinan Keramik S Soeharto Kota Malang, Kerajinan Tangan Yan's Keramik, Kerajinan Keramik CN di Dinoyo Malang, Kerajinan Kayu Jati (Meubel), Kerajinan Meubel Jati Bersama di Lowokwaru Malang, Kerajinan Tangan Pigura, Kerajinan Tangan Labunte, Kerajinan Tangan Ukir Batu Marmer Art Galery 99, Kerajinan Patung Semen, Kerajinan Seni Lukis Tempat Sampah dari Ban Bekas, Kerajinan Seni Lukis "Galeri Oejik" di Kota Malang, Kerajinan Seni Lukis Karya Rizky Rachmadhansyah di Sawojajar Malang, Kerajinan Lukisan Herry Arema Gallery, Kerajinan Sanitair Hance, Kerajinan Mosaik Batu Pada Pot Bunga, Kerajinan Vandel Kerajinan Tangan Kartu Undangan Sisi Lain Sawojajar Malang, Kerajinan Cetak Sablon Almas Printing, Kerajinan Sandal Ukir, Kerajinan Tangan Sepatu Kulit Kerajinan Tangan Rumah Pasir di Kota Malang, Kerajinan Tangan Pasir Laut Omah Pasir, Kerajinan Lampion Cempaka, Kerajinan Lampion Joeanda Shop Kampung Lampion Spesial Handicraft.

Ragam jenis-jenis kerajinan tangan tersebut dapat dikelompokkan berdasarkan: (1) fungsi atau manfaat produk/benda kerajinan yang dihasilkan, (2) jenis bahan pokok (utama) baik bahan alam atau bahan buatan parik yang digunakan untuk membuat produk kerajinan, dan (3) teknik seni/cara pembuatan kerajinan tangan yang dipilih sesuai karakteristik jenis kerajinan yang dihasilkan. Hal ini sesuai dengan Raharjo (2011), bahwa pada intinya jenis seni kerajinan diklasifikasikan berdasarkan segi teknis yaitu seni ukir, seni keramik, seni anyam, seni tenun, dan seni batik dan lainnya. Pengelompokan jenis-jenis kerajinan tangan ini dimaksudkan untuk lebih memudahkan dalam memahami hasil pemetaan suatu produk benda kerajinan yang ada di Malang. Beragam jenis kerajinan tangan bisa saja dibuat dari bahan yang sama dan teknik pembuatan yang sama; namun memiliki fungsi atau pemanfaatanya bisa berbeda. Demikian juga atau sebaliknya ada produk kerajinan tangan yang funsgsi atau pemanfaatannya sama, namun dibuat dari bahan (material) yang berbeda, dan dikerjakan oleh pengrajin dengan teknik seni yang berbeda pula.

Secara spesifik pemilik usaha kerajinan tangan dengan cermat memilih atau memberi nama pada produk kerajinan yang dibuatnya dengan memunculkan nama jenis bahan utama yang digunakannya. 


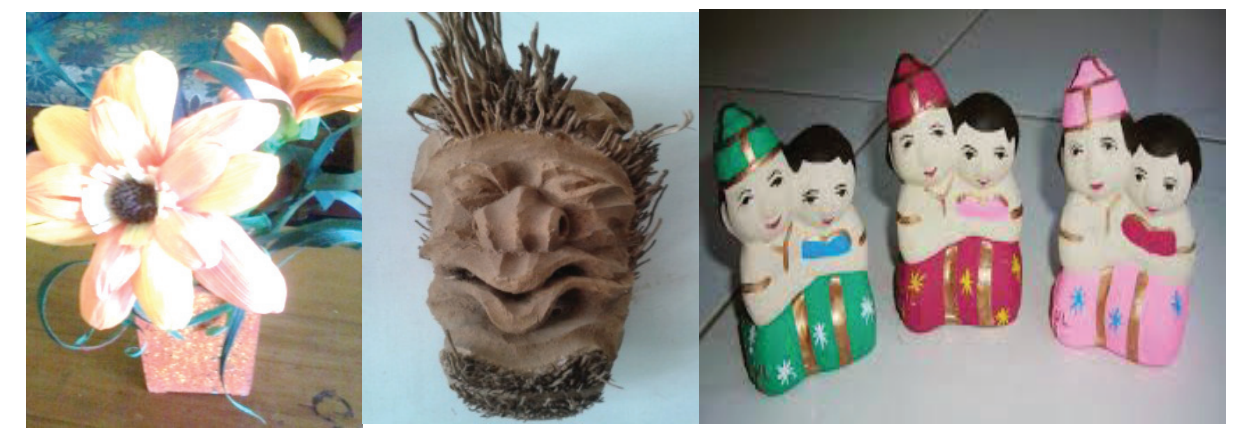

Gambar 1. Contoh kerajinan Gerabah, Kerajinan Akar Bambu , Kerajinan Klobot Jagung

Kemunculan nama bahan pokok pada usaha kerajinan tersebut tentunya akan memudahkan seseorang untuk mengenali dan memahami karakteristik jenis kerajinan, fungsi dan model produk yang dihasilkannya. Seperti sebutan kerajinan ukir akar bambu, kerajinan ukir kayu jati, kerajinan pasir laut dan lainnya.

\section{Keragaman Model Produk Kerajinan Tangan sebagai Sumber Belajar SBdP SD}

Model produk kerajinan tangan yang ada di Kota Malang difokuskan pada: (1) wujud produk sesuai jenis-jenis karya yang ada disetiap lokasi home industry kerajinan tangan, (2) karakteristik keindahan model/wujud kerajinan tangan, dan (3) keragaman model produk kerajinan sesuai besarkecil ukurannya. Beragam jenis benda kerajinan tangan yang merupakan hasil keterampilan kreatif para Pengrajin dalam mengolah atau memanfaatkan bahan alam atau bahan buatan secara umum ada yang modelnya sebagian berwujud dua dimensi (dwimatra), sebagian besar berwujud tiga dimensi (trimatra), dan sebagian kecil ada yang wujudnya cenderung dua-tiga dimensi. Secara umum model/ produk kerajinan tangan yang dihasilkan di 34 tempat usaha home industry di wilayah kota Malang wujudnya sebagaian besar tiga dimensi (trimatra), dan sebagian kecil menghasilkan model/ produknya berwujud dwimatra (dua dimensi). Fakta mengenai wujud model/produk karya sesuai jenisjenis kerajinan dari hasil pemetaan adalah sebagai berikut.

Model produk kerajinan tangan di wilayah Kota Malang yang wujudnya tiga dimensi (trimatra) yaitu: kerajinan Akar Bambu Galery 76 di Kebon Agung 28 Malang, kerajinan Akar Bambu Krepek Dongkrek di Jalan Galunggung 48a Malang, kerajinan Rotan Tiban Jaya Rotan di Jalan Pahla- wan 249A Balearjosari. Kerajinan Bunga Klobot Jagung Garuda Yaja Florist di Jalan Dirgantara IIc No.29 Malang. Kerajinan Bunga Kering \& Sisisk Ikan di Jalan Jaksa Agus Suprapto III No.83 Malang. Kerajinan Bunga "Grafing Yadi" di Jalan Jaksa Agung Suprapto III Rampal Claket 83 Malang. Kerajinan Gerabah Potleri Seni Kriya di Jalan Mayjen Panjaitan No. 221 RT 04/RW 06 Malang. Kerajinan Gerabah Maron Jaya Art Shop di Jalan Mayjend Panjaitan Gang 17A No.72, Malang. Kerajinan Gerabah Pisang di Jalan Jaksa Agung Suprapto III Rampal Claket No.83 RT.1 Rw.01 Malang. Kerajinan Gerabah Hias di Jalan MT. Haryono XID/474 Dinoyo Malang. Kerajinan Boneka Bonshop di Jalan Laksda Adi Sucipto Gg.7A No 17 Blimbing. Kerajinan Keramik S Soeharto di Jalan Mayjen Haryono XI/461, Kerajinan Keramik Yan Keramik di Jalan MT. Haryono No.467 Dinoyo Malang. Kerajinan Keramik KM, Toko CN di Jalan MT Haryono Gang XI Dinoyo Malang, Kerajinan Mebel Ukir Kayu Majapahit di Jalan Ikan Piranha No. 66, Kemirahan Malang. Kerajinan Mebel Ukir Kayu Jati Bersama, di Jalan Ikan Piranha Atas, Lowokwaru, Malang. Kerajinan Pigura Istana Pigura, di Jalan Raya Tlogomas No.46 Lowokwaru. Kerajinan Lambute di Jalan Polowijen I Gang IX No.31C RT.02 RW.01 Polowijen Blimbing Malang.

Pada gambar 2, Sabun mandi bekas dicampur dengan tepung terigu dan dipoles menggunakan pewarna makanan, ternyata bisa menjelma sebuah karya seni bercita rasa tinggi.

Kerajinan Patung di Rt.03 Rw.07 Tlogomas Lowokwaru Malang. Kerajinan Ukir Batu Art Galery 99 di Jalan Kaliurang No.15 Malang. Kerajinan Sanitair Pot Pak Hance di Jalan Raya Candi II Karangbesuki Malang. Kerajinan Mosaik Pot Pak Rofii di Jalan Kintamani No.20 RT.4/RW.8 Penanggungan. Kerajinan Vandel di Jalan Gajayana No 580 A Ketawangede Lowokwaru Malang. 


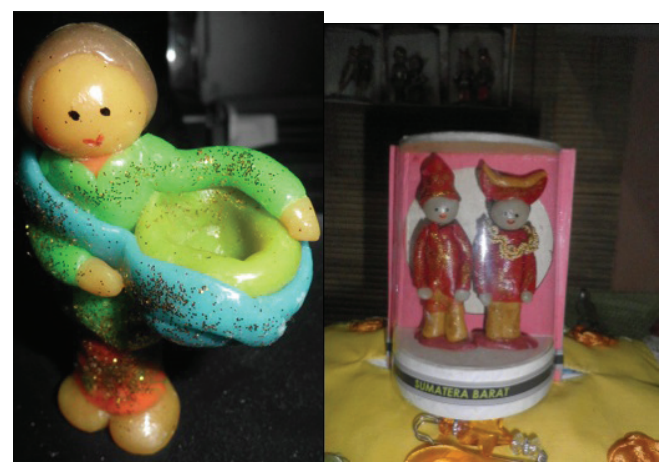

Gambar 2. Contoh kerajinan Lambute adalah singkatan dari larutan sabun dan tepung.

Kerajinan Sandal Ukir, di Jalan Laksda Danau Laut Tawar II G3/F4 Sawojajar I Kedung Kandang. Kerajinan Sepatu Kulit di Jalan Gadang G.6 No.19 RT. Kerajinan Pasir Laut Rumah Pasir di Jalan Mawar Nomor 17 Lowokwaru Kota Malang, dan Kerajinan Pasir Laut Omah Pasir di Jalan Asahan 4, Blimbing Malang.

Model produk kerajinan tangan di wilayah Kota Malang yang wujudnya dua dimensi (dwimatra) yaitu: kerajinan Bunga Duka $R$ di Jalan Galunggung 92, Malang, kerajinan Batik Celaket di Jalan Jaksa Agung Suprapto II No.71 Malang. Kerajinan kain Flanel Gerai Flanel AZ-KA Handycraft di Jalan Danau Maninjau Selatan D1 D21 Sawojajar Malang, kerajinan kain Flanel Merajut di Jalan Danau Semayang XI C1/I4 Sawojajar Malang. Kerajinan lukisan Oejik Galery di Jalan Tanimbar 3 Malang. Kerajinan lukisan Risky Rahmandiyan di Jalan Danau Brantan Timur 2F4 Sawojajar Malang. Kerajinan lukisan Herry Arema Gallery di Jalan Ahmad Yani No.74, Klojen Malang. Kerajinan Cetak Sablon Sisi Lain di Jalan Danau Kerinci IIE 5 E No.14 Sawojajar Malang. Kerajinan Cetakk Sablon Almas Print di Jalan Ki Ageng Gribig 2 RT.03 Rw 04 Madyopuro Kedungkandang Malang.

Mengenai karakteristik keindahan yang ada pada model produk kerajinan tentunya secara prinsip tidak dapat dipisahkan dari kajian struktur fisik (visualisasi) karya seni kerajinan sebagai benda terapan, benda fungsional, benda hias yang wujud tampilnya bagus, menarik, rapi, indah, alami, serta memenuhi persyaratan fungsional praktis. Struktur fisik benda kerajinan terlihat pada tampilan bentuknya, ukuran, warna, kesan bahan, kualitas teknis pembuatannya. Karakteristik keindahan model/ produk kerajinan tangan di Malang diberikan analisis berdasarkan struktur fisik berikut ini.
Pertama, pada kerajinan tangan akar Bambu dihasilkan model produk karya yaitu patung figur manusia, binatang obyek burung dengan berbagai ukuran sesuai akar bambu yang dipahat. Model karya sebagian berwarna polos (alamiah) berkesan tekstur serat akar bambu, dan sebagian ada yang diwarna, vernis. Kedua pada produk kerajinan rotan dihasilkan model produk benda pakai yaitu meja, kursi, keranjang, pot bunga, penyekat ruangan (sketsel), almari/rak dengan kreasi model beberapa ukuran kecil, sedang, dan besar. Ketiga, ditempat usaha kerajinan Meubel ukir kayu Jati dihasilkan model/produk berupa meja, kursi, tempat tidur, almari berbagai ukiuran dan model kreasi. Keempat, kerajinan gerabah dan Keramik yang ada di kampung Dinoyo Malang menghasilkan beragam model produk karya antara lain Guci besar dan kecil, Wadah Pensil Kura-kura, Pot Bunga, Tempat Payung, Vas Bunga, Celengan, Asbak, model Binatang, dan kreasi lainnya. Model kerajinan gerabah dan keramik tersebut dibuat berbagai ukuran ada yang kecil, sedang dan ada yang besar. Kesan penampilan keindahnnya ada yang polos warna natural alamiah dan ada yang bermotif hias, kaligrafi dan ukiran ragam hias yang indah. Kelima, kerajinan limbah klobot jagung dapat dibentuk berbagai model hiasan rumah dan aksesoris. Karya kerajinan tangan klobot jagung juga memiliki nilai estetika, dan memiliki nilai jual yang sangat tinggi. Keenam, kerajinan sanitair menghasilkan model produk berupa air mancur, lampion, kijing makam, nisan, pilar, cuci piring beton, pot bunga, ornamen taman, hiasan air mancur, bermacam hiasan dinding antara lain patung, relief, sangkar burung, pagar plesir, plafon ornamen, dan lain-lain. Motif kerajinan sanitair yang diterapkan biasanya berupa motif geometris, tumbuh-tumbuhan, dan sedikit 
motif bentuk alam. Contohnya yaitu motif bunga, segi enam, motif daun mawar, dan motif bintang. Bentuk ukirannya juga bermacam-macam yakni bergelombang-gelombang, garis horizontal dan vertikal.

\section{PEMBAHASAN}

Dikelompokkan berdasarkan fungsi atau pemanfaatan ada sebagian produk kerajinan yang disesuaikan dengan nama sebutannya, yaitu: (1) kerajinan tangan yang dibuat dengan orientasi fungsi praktis atau terapan. dan (2) kerajinan tangan yang dibuat dengan fungsi utama sebagai karya seni atau benda hias untuk dinikmati kesan atau nilai keindahannya. Contoh kerajinan tangan yang memiliki fungsi praktis atau terapan yaitu kerajinan Sandal, Sepatu, dan Meubel. Contoh kerajinan tangan yang difungsikan sebagai benda seni atau benda hias yaitu kerajinan lukis, kerajinan patung, kerajinan lampion, kerajinan akar bambu, kerajinan merangkai bunga dan lainnya. Dari sejumlah jenis kerajinan tersebut memperlihatkan ada fungsi yang terkait dengan nama atau sebutan yang diberikan. Dalam kaitannya dengan fungsi atau pemafaatan produk kerajinan yang dihasilkan oleh para pengrajin di Malang tersebut digunakanlah nama atau sebutan usaha kerajinan yang dilakukan sesuai spesifikasi dan kreasi barang yang dibuatnya.

Ada juga ragam kerajinan yang fungsinya sebagai barang (benda) mainan, contohnya kerajinan boneka. Selain itu ada juga jenis kerajinan tangan yang dibuat dengan fungsi untuk menaruh, menyimpan, atau sebagai bagian untuk memperindah barang/karya seni. Contohnya adalah kerajinan Pot Bunga, kerajinan Pigura, dan lainnya. Sedangkan sebagian jenis kerajinan yang ada di Kota Malang dapat dikenali dan dipahami dari: (a) jenis bahan yang digunakan, misalnya kerajinan akar bambu, kerajinan pasir laut, kerajinan klobot jagung, bunga kering, kerajinan kain flanel, kerajinan rotan. (b) dari teknik atau cara pembuatann, contohnya kerajinan gerabah, kerajinan keramik, kerajinan batik, kerajinan anyaman, kerajinan merajut, kerajinan ukir, kerajinan cetak sablon, kerajinan lukis dan lainnya.

Dari uraian di atas dapat ditegaskan bahwa keberagaman produk kerajinan tangan yang ada di wilayah Kota Malang merupakan wujud kongkrit prilaku produktif dari sebagian masyarakat yang memiliki potensi keterampilan kreatif seni.
Didukung oleh (Sumanto, 2015) bahwa keragaman model/produk kerajinan tangan menujukkan adanya keunikan dan keindahan pada setiap hasil usaha kerajinan yang ditekuninya. Dalam kaitan ini komunitas masyarakat di Malang memiliki kepedulian bekerja secara aktif, gigih, tekun, ulet dalam upaya meningkatkan kualitas kebutuhan dan kesejahteraan diri, keluarga serta kehidupan di wilayah Malang.

Dari hasil pemetaan home industry kerajinan tangan di Kota Malang tersebut dapat dikelompokkan berdasarkan jenis bahan pokok (utama) yaitu kerajinan Akar Bambu, Rotan, Kayu Jati, Bunga Kering, Batu Marmer, Sisik Ikan, Klobot Jagung, Batu Kali, Pasir Laut, Batang Pisang Kering, Kain Flanel, Kertas, Ban Bekas, Tanah Liat, dan lainnya.

Pada hasil pemetaan jenis kerajinan tangan yang dikelompokkan berdasarkan teknik seni (cara pembuatan) yaitu kerajinan Gerabah, Keramik, Ukir Kayu, Batik, Merangkai, Memahat, Cetak Sablon, Mosaik, Merajut dan lainnya. Sebutan Lukis, Ukir, Batik, Gerabah dalam lingkup karya senirupa merupakan bagian dari teknik yang secara khusus diterapkan dalam pembuatan suatu produk atau karya kerajinan. Pemahaman teknik seni kerajinan tangan tersebut berkaitan dengan karakteristik caracara membuat karya kerajinan tangan yang merupakan bagian dari keragaman cara berkreasi karya seni murni dan seni terapan.

Diantaranya "Lukis" atau "Melukis" adalah suatu teknik berkarya seni rupa yang dilakukan dengan menggoreskan cairan tinta/car/pewarna lukis dengan menggunakan bantuan alat kuas di atas bidang lukisan (kanvas). Hanya saja dalam kegiatan kerajinan kaca lukis peralatan yang digunakan tentunya disesuaikan dengan karakteristik bidang lukisan yantu lembaran kaca. Demikian juga "Ger$a b a h "$ atau ada yang menyebut "Tembikar" adalah suatu teknik berkarya seni kerajinan tangan dengan menggunakan bahan utama berupa tanah liat. Pembuatan kerajinan gerabah dapat dilakukan dengan teknik tertentu yaitu teknik pilin, putar, dan lainnya. Dinyatakan bahwa jenis kerajinan yang menggunakan bahan baku dari tanah liat yang melalui proses sedemikian rupa (dipijit, butsir, pilin, pembakaran dan glasir) sehingga menghasilkan benda pakai dan benda hias yang indah. Contoh: gerabah, piring dan lain-lain. Demikian juga teknik "ukir" atau pahat merupakan salah satu cara membuat karya seni kerajinan yang dilakukan dengan menggunakan bantuan alat pahat/tatah. 
Pengetahuan mengenai keragaman jenis-jenis kerajinan tangan, fungsi kerajinan tangan yang ada di kota Malang inilah yang dapat dimanfaatkan secara kontekstual sebagai sumber belajar SBdP bagi anak-anak di SD. Melalui pengembangan materi muatan seni budaya dan prakarya berbasis ragam kerajinan tangan daerah setempat ini dapat disesuaikan dengan pemetaan kompetensi dan indikator yang ada ada pembelajaran-pembelajaran pada setiap subtemanya. Contoh di Kelas VI pada tema 5 "Wirausaha" subtema 1, "Kerja Keras Berbuah Kesuksesan" dapat memanfaatkan sumber belajar mengenai ragam produk kerajinan tangan daerah setempat. Implementasi kegiatan dalam pembelajaran dapat dikaitkan dengan kegiatan "ayo mencoba" atau "ayo berkarya". Sebagaimana buku siswa yaitu "Pernahkah kamu membuat kreasi dari koran bekas? Salah satu kreasi dari koran bekas adalah celengan. Mari kita coba....”. Dengan mengetahui, mengenal, dan memahami keragaman produk home industry kerajinan tangan yang ada dilingkungan sekitar diharapkan akan dapat memberikan dampak yang positif dan konstruktif, serta memicu tumbuhnya kompetensi kreatif dan sikap apresitif bagi kemajuan hasil belajar anak.

Dari penggambaran bermacam-macam model produk kerajinan tangan yang ada di Malang tersebut adanya faktor keterampilan dan kreatifitas Pengrajin yang akan berdampak pada kualitas model kerajinan yang dihasilkan, sesuai jenis bahan yang dipilihnya. Dengan memperhatikan selera/ kebutuhan konsumen, dan ditunjang pemanfaatan teknologi dibidang industri kerajinan, para pengrajin dituntut untuk terus mengembangkan model/produk kerajinan yang berdaya saing dipasaran sesuai teknik seni yang diterapkannya. Pemanfaatan teknik-teknik kerajinan dalam pembelajaran di SD dapat diwujdkan melalui pendekatan saintifik dari bahan alam dan buatan yang ada dilingkungan sekitar (Sumanto. 2017:37).

Dengan mengetahui, mengenali, dan memahami keragaman model produk kerajinan yang ada dilingkungan sekitar diharapkan akan dapat memberikan dampak yang positif dan konstruktif, serta memicu tumbuhnya sikap apresitif positf bagi kemajuan belajar anak. Ketercapaian kompetensi muatan materi SBdP bagi siswa SD dapat dilakukan dengan sesuai bentuk pemanfaatan kerajinan tangan sebagai sumber belajar diantaranya: (a) sebagai obyek yang dipelajari oleh siswa, (b) sebagai bahan pembe-lajaran berolah seni, bereksplorasi seni, (c) sebagai sumber ide dalam berolah seni, (d) sebagai obyek apresiasi, dan (e) sebagai model atau contoh tatanan seni (Sumanto, 2005). Contoh pada pembelajaran di kelas IV tema "Berbagai Pekerjaan", subtema "Jenis-jenis Pekerjaan" dan "Pekerjaan Orang Tuaku" sangat relevan dan tepat jika keberdaan model produk kerajinan tangan di lingkungan setempat dimanfaatkan sebagai sumber belajar. Dalam kaitan ini pengetahuan mengenai keragaman model produk kerajinan tangan yang ada di Malang inilah yang dapat dimanfaatkan secara kontekstual sebagai sumber belajar bagi anakanak di SD.

\section{SIMPULAN DAN SARAN}

\section{Simpulan}

Pertama, kerajinan tangan di Kota Malang secara umum adanya keberagaman jenis dan model kerajinan yang memiliki nilai keindahan, nilai ekonomis, yang dapat dimafaatkan sebagai sumber belajar di SD. Keberagaman jenis-jenis kerajinan di Malang merupakan wujud kongkrit prilaku produktif sebagian masyarakat yang memiliki potensi keterampilan kreatif seni. Komunitas pengrajin di Malang memiliki kepedulian bekerja secara aktif, gigih, tekun, ulet dalam upaya meningkatkan kualitas kebutuhan dan kesejahteraan diri, keluarga serta kehidupan di wilayah Kota Malang. Jenis-jenis kerajinan tangan di Kota Malang yaitu: kerajinan akar bambu, anyaman rotan, bunga klobot jagung, sisik ikan, bunga kering, merangkai bunga ucapan duka cita, gerabah, gerabah pisang (graping), batik tulis, boneka kain, kain flanel, merajut, keramik, meubel, pigura, labunte, ukir batu marmer, patung semen, seni lukis tempat sampah, seni lukis, sanitair, mosaik batu, vandel, kartu undangan, cetak sablon, sandal ukir, sepatu kulit, pasir laut, dan kerajinan lampion. Kedua, model produk kerajinan tangan yang wujudnya trimatra yaitu: kerajinan akar bambu, kerajinan rotan, merangkai bunga, gerabah boneka, keramik, meubel ukir kayu. pigura, lambute, patung, ukir batu, sanitair pot, sandal ukir, sepatu, pasir laut, dan kerajinan lampion. Model/produk kerajinan tangan dwimatra yaitu: kerajinan bunga duka, batik, kain flanel merajut, lukisan, dan cetak sablon. Karakteristik keindahan produk kerajinan secara prinsip ada pada struktur fisik (visualisasi) karya seni kerajinan sebagai benda terapan, benda 
fungsional, benda hias yang wujud tampilnya bagus, menarik, rapi, indah, alami, serta memenuhi persyaratan fungsional praktis. Struktur fisik benda kerajinan terlihat pada tampilan bentuknya, ukuran, warna, kesan bahan, kualitas teknis pembuatannya. Dilihat dari kecermatan pembuatannya dapat memberikan kesan keindahan, kehalusan pada proses pengerjaannya, dimana membutuhkan keuletan dan kesabaran serta tingkat kerumitan tersendiri.

\section{Saran}

Masih diperlukan pemetaan lanjutan dengan tujuanagarsemuausahahomeindustrykerajinanyang ada diseluruh wilayah Kota Malang dapat dipetakan berkaitan dengan keragaman jenis kerajinan, model/ produk kerajinan yang dibuat, teknik kerajinan yang dipilih, dan bahan (material) serta peralatan yang digunakan. Perlu ditindaklanjuti dengan penelitian mengenai "Manajemen Pengelolaan Usaha Home Industry Kerajinan Tangan yang ada di Kota dan Kabupaten Kota Malang”, dan penelitian mengenai "Model Pemasaran Produk Kerajinan Tangan di Kota Malang".

\section{DAFTAR RUJUKAN}

Bogdan, R.C dan Biklen, S.K. 1992. Qualitative Reseach for Education An Introduction to Theory and Method. Boston: Allyn and Bacon, Inc.

Raharjo, T. 2011. Seni Kriya \& Kerajinan. Yogyakarta: Program Pascasarjana Institut Seni Indonesia Yogyakarta.

Rokhmat, N., Triyanto \& Rondhi, M.. 2004. Profil Wanita dalam Karya Seni Reklame Visual. Semarang: Jurnal Imajinasi. FBS UNNES.
Rohidi. TR. 2000. Kesenian dalam Pendekatan Kebudayaan. Bandung: Penerbit STSI.

Sanaky, Hujair AH. 2009. Media Pembelajaran. Yogyakarta: Safiria Insania Press.

Suharto, S. 2007. Refleksi Teori Kritik Seni Holistik: sebuah Pendekatan Alternatif dalam Penelitian Kualitatif bagi Mahasiswa Seni (Reflection on Art Criticism and Holistic Art Criticism: an Alternative Approach of Qualitative Research for Art Students). Harmonia: Journal of Arts Research and Education, 8(1).

Sumanto. 2005. Pengembangan Kreativitas Senirupa Anak TK. Jakarta: Dirjen Dikti.

Sumanto. 2011. Pendidikan Senirupa di Sekolah Dasar. Malang: FIP UM.

Sumanto. 2015. Kerajinan Tangan di Blitar sebagai Sumber Belajar Seni Budaya dan Prakarya (SbdP) Sekolah Dasar. Jurnal Sekolah Dasar tahun 26 Nomor 2, Nov 2015. hal 121. Malang. Jurusan KSDP FIP UM.

Sumanto. 2017. Ragam Teknik dan Bahan Kerajinan Tangan sebagai Sumber Belajar Seni Budaya dan Prakarya Sekolah Dasar. Jurnal Sekolah Dasar tahun 26. Nomor 1, Mei 2017, hal.37. Malang: Jurusam KSDP FIP UM.

Suprayekti, 2004, Pembaharuan Pembelajaran di SD. Jakarta: Pusat Penerbitan UT.

Vygotsky. 2000. The Social Formation of Mind in Driscoll, M.P. Psychology of Learning for Instruction, $2^{\text {nd }}$ ed. Boston: Allyn \& Bacon,. 